\title{
Regional Private Farming: from Theory to Practice
}

\author{
Goncharenko O.N. \\ Federal State Budgetary Educational Institution of Higher \\ Education, Northern Trans-Ural State Agricultural \\ University \\ 7, Republic street, Tyumen, 625003, the RussianFederation \\ goncharenko-65@mail.ru
}

\author{
Medvedeva L.B. \\ Federal State Budgetary Educational Institution of Higher \\ Education, Northern Trans-Ural State Agricultural \\ University \\ 7, Republic street, Tyumen, 625003, the RussianFederation \\ medvedevalb@mail.ru
}

\begin{abstract}
The paper considers the experience of private farming in the agro-industrial region, based on the theoretical insights of prominent Russian economists including A.V. Chayanova. Through output statistics, expert interviews as of 2018 and the results of the 2016 survey, it reveals the main positive phenomena in the development of this sector of agricultural society, particularly, steady growth at the institutional entities. It defines the main challenges due to the lack of awareness among rural residents about the institution of private household economy as such and the role of cooperation. The evaluation concludes that along with direct state support for household plots, state and municipal authorities need to provide training to agricultural workers.
\end{abstract}

Keywords - private household plot, backyard, food production, A. V. Chayanov, government support, agricultural cooperative

\section{INTRODUCTION}

At the present stage of agricultural development, family farms or household plots (LPKh) attached to a rural residence, that are an integral part of the entire agricultural production, have acquired the most important socio-economic importance. In addition, they serve as a "niche" where unemployed villagers can get a job, as well as economic and labor socialization of children and youth. Meanwhile, due to agrarian reforms carried out throughout the $20^{\text {th }}$ century in Russia, in the face of uncertainties, it was subsidiary household plots that turned out to be the most mobile economic unit. They not only saved production rates but increased them as well. This circumstance is the main distinguishing feature of household plots functioning at the present stage. [7, p. 3] The significance to develop these farms is strengthened by the State program for the Development of Agriculture and regulation of agricultural products, raw materials and food for 2013-2020, as well as the federal target program Sustainable Development of Rural Areas for 20142017 and for the period until 2020 that are a logical continuation of the federal target program Social Development of the Village until 2013. Being implemented the latter demonstrated positive changes in the integrated development of rural areas. This created certain prerequisites for fostering their productive and infrastructural potential. It contributed to increasing employment and incomes of the rural population and improving their living conditions and social environment [9]. The research on the status, development and regulation of family farms enables to determine the most promising ways of their further development within the Russian agro-industrial system. This is done with respect to regional production features, since each region besides climatic and natural features has its own administrative traits that regulate food production, cooperation and state support. In the mean time, the development of family farms is a historically complex and unequivocal process that was mentioned in the publications of social scientists, such as S.N. Bulgakov, A.V. Chayanov, M.I. Tugan-Baranovsky, P.A. Kropotkin and other Russian and foreign authors. Their works defined goals, objectives and components of private farming infrastructure. However, in theory and practice, many methodological aspects of the formation and functioning of household plots in modern conditions remain unresolved with regional peculiarities not being addressed.

The given study aims to respond to economic and theoretical conclusions as well as practical experience of the functioning and development of regional subsidiary household plots in the Tyumen region.

\section{SUBJECTS AND METHODS}

The object of study is subsidiary household plots in agricultural areas of the Tyumen region.

The structural-functional approach forms the methodological basis. In this respect, LPKh being an institution of rural self-employment comprises a subject and an object of relationship, as well as functions performed by subjects while implementing these relations.

Both the actual institutional entity and the institutional agent can be attributed to the subjects of the institution of subsidiary household plots as such. With regard to subsidiary household plots, this means that the former is concerned with primary employment of the population while the latter - with secondary. Moreover, in either case, the nature of employment itself can be both market-oriented and non-market (selfsustaining).

Institutional entities (agents) of household plots are the entire working population, including both economically active and inactive population.

The object of the relationship of institutional entities (agents) in household plots are the norms and rules regulated by the legislation of the Russian Federation and regional laws. The informal nature of the relationship at the institution of LPKh is due to the fact that it represents the framework of 
economic activities within the household. Moreover, LPKh economic activity is viewed as the one required for an individual to be sustainably self-sufficient.

The methods of study include abstract logical, comparative, sociological survey, economic and statistical, and others. When writing the article, formalized interviews were carried out with experts in the field of household plots (n-15). The employees of the department of the agro-industrial complex of the Tyumen region, heads of cooperatives, and peasants involved in personal households took part in the interviews. The survey was conducted in February-May 2018. To ensure data analysis and verification, the authors [3] used the survey results derived in March-September 2016 in 8 districts of the Tyumen region by means of the questionnaire "Household Plots: Current Status and Development Paths". The selection totals 400 households. All respondents are residents of rural areas, $22.1 \%$ of villagers have a private household plot. Besides, the majority (84.9\%) maintain households and have a permanent job at different organizations or enterprises, and some (16.1\%) are unemployed but keep their private subsidiary plot. $57.1 \%$ are women, $42.9 \%$ are men. Regarding education, $34.3 \%$ hold a degree, $14.3 \%$ have incomplete higher education, $11.4 \%$ have secondary technical education, $22.9 \%$ - special secondary and $17.1 \%$ - secondary education. Regarding social position, $57.1 \%$ consider themselves to be workers, $20.8 \%$ to be employees, $22.1 \%$ to be peasants. For $71.4 \%$ of the respondents, the village is a permanent place of living, $25.7 \%$ live there for over 10 years, in other words, the majority of the respondents are indigenous people.

\section{RESULTS}

Many well-known agricultural scientists addressed the problems of the formation and development of peasant (farmer) household plots. Fundamental research in this area was carried out by such scientists as S.N. Bulgakov, V.F. Levitsky, A.V. Chayanov, N.P. Makarov and others. In general, various authors describe two basic concepts of peasant farming, namely:

1. The concept of a peasant farming as an entrepreneurial enterprise, in which the owner hires himself as a worker. "The motivation of a peasant entrepreneur is to obtain the difference between gross profit margin and production costs as a result of investing their capital into a business." This concept is possible 'only in a capitalist regime'.

2. The concept of a peasant business as a family operated farm, in which the family receives a single labor income and coordinates their efforts with the obtained material output as a result of the annual labor costs. This concept exists in a non-capitalist regime. [1, p. 23.24]

The authors believe that the agrarian-economic concept introduced by A. V. Chayanov [13] is increasingly important to ensure sustainable development of LPKh. The concept first appeared in Russia in the early $20^{\text {th }}$ century and resulted from the new agro-industrial thinking. That led to the crisis of landowner farming on the one hand and on the other hand to the rapid development of peasant farming. A.V. Chayanov in his works puts the labor of a peasant and his family at the forefront. Thus, as early as 1911, he gave a classic definition to the goal of a peasant economy: "The task of peasant farming is to deliver subsistence to the family by making the most complete use of input supply and workforce available" [13]. The scientist opposed such management to capitalist entrepreneurship based on hired labor. Family operated farming wasn't considered isolated, and in his work the Russian economist showed the need for cooperation and its integration in the national economy. The scientist dwelt on some factors impacting profitability of peasant farms, which he divided into two groups, namely, on-farm and nationaleconomy. The main on-farm factors were, in his opinion, family labor resources and labor intensity. He substantiated a very significant view as to why there is no wage category in a non-capitalist economy and how it is transformed into the net income of the family. He was the first to express the idea of self-supporting income distributed among all members of the workforce equally, and presented the sustainability and survival strategies of such team. A.V. Chayanov formulated the problem addressing the correlation of components in a peasant business including arable land, labor, income, livestock, equipment, etc., which can be seen as a distinctive scientific milestone. He studied the transformation of a family operated household into a farm enterprise. He believed that the greatest attention should be paid to the direct reformation of family households into farm enterprises based on the use of hired labor to obtain surplus value. In this situation the only possible solution to integrate the elements of large-scale industry, industrialization, etc. into peasant economy is the way of cooperative collectivization, gradual and consistent split of individual branches from private households and their arrangement into large public enterprises. Chayanov [14] attributed further development of labor farms to gradual cooperation with no hired labor. He proposed a multifaceted scheme to differentiate the peasantry against industrial and social grounds, substantiated the path of cooperative collectivization that resolved the contradictions in the village by peaceful economic methods. At the same time, family selforganized agriculture is impossible without all family farms being united, which makes it possible to increase labor productivity, establish joint marketing of products, and provide various facilitation measures. Many Russian advocates of cooperation formed their views under the influence of Western European representatives of this direction. Among them are R. Owen, Ch. Fourier, F. Lassalle, Saint-Simon, H. Schulze-Delitzsch, and others. F.J. Turner, N. I. Ziber, N.P. Balin, K.A. Pozhitnov, V.F. Totomiants, M.I. Tugan-Baranovsky, A.V. Chayanov, and others made a significant contribution to the development of the cooperation theory. P.A. Kropotkin widely developed and substantiated the idea of mutual assistance as a universal law for all living beings. He concluded [5] that one of the newest evolutionary manifestations through the world law of mutual economy assistance is cooperation that results in the highest form of economic relations. The scientist appealed to cooperation and to its entities, particularly, cooperatives as a tremendous social driver capable of taking on global social tasks. A. A. Nikonov [7] consistently defended the idea of reviving the cooperative mainstream in the agrarian sphere of Russia. He argued that the lack of a well-tailored cooperation system in agriculture 
"does not allow to solve many economic problems, to protect the peasant from exorbitant demands of commercial banks and the state as such, to establish sales, supply, storage, processing and sales of products." Meanwhile, he noted that "the very idea of cooperation in our country has been repeatedly discredited, distorted and debased" [7].

As a consequence, theoretical implications of outstanding Russian scientists enable to assume that household plot is a legal form of agricultural production based on family selforganized labor and cooperation of small owners. The demand for LPKh at the initial stage is due to the low standard of living among the rural population, which allows farm participants to meet their needs for basic food and to have additional sales proceeds from surplus agricultural products obtained by their own labor through the rational use of labor, material and land resources.

The agricultural complex of the Tyumen region experienced a long period of structural reformation, during which it was necessary to target the production of agricultural products at the demands of consumers, improve the quality and range of products, reduce resource and labor intensity of products. During agrarian reforms, under various uncertainties, it was the households that turned out to be the most mobile economic unit. They not only saved production rates, but also increased them. In March 1998, the Regional Duma of the Tyumen Region adopted the Law on Household Plot [9], developed in accordance with the Constitution of the Russian Federation, the Civil Code of the Russian Federation, the Code of Labor Laws of the Russian Federation, the Law of the Tyumen Region on the Simplified Tax, Accounting and Reporting System for Small Businesses. The law defines the socio-economic, organizational and legal framework for household plots, provides them with state and public support, conductive regulation, increased marketability, development of cooperative ties and optimization of relations with large enterprises in the sphere of production and circulation. According to this law, a household plot is a farm owned by residents of the Russian Federation, foreign citizens and stateless persons who have permanent residence in the Tyumen region, and are involved in agricultural production. Household farming can be either complementary or single (for the retired, housewives, the unemployed, and others) occupation. Products and income derived are the property of citizens and can be used at their discretion - both for their own consumption and for sale.

By early 2000, the share of households in the total structure of agrarian producers reached almost $50 \%$. This trend towards an increasing number of household plots is continuing at present. By 2015, the share of small businesses in the Tyumen region amounts to $50.5 \%$ and $48.4 \%$ accounts for the share of agricultural organizations in the total agricultural production. At the end of 2017 , over $47.6 \%$ (36.2 billion rubles) of agricultural goods in the region were produced by private farms. Traditionally, the production of potatoes and vegetables prevails. Totally, in 2016, 172,000 household plots, over 900 peasant farms and 115 agricultural consumer, credit and marketing cooperatives are registered in the region. At the same time, farms of this sector including households, peasant farms and individual entrepreneurs produced $48.4 \%$ milk, $38.1 \%$ meat of all kinds, $72.5 \%$ potatoes and $69.7 \%$ vegetables to the total economic output in the agricultural sector [4].

The statistics is confirmed by the poll among rural residents through the questionnaire "Private Household Plots: Current Status and Development Paths" (2016), the most common types of farming include: potato farming with $85 \%$ of respondents involved, vegetable farming $-62 \%$, pig breeding $-50 \%$, cattle breeding - $48 \%$, less common poultry $-29 \%$, sheep $-23 \%$, picking up wild plants $-14 \%$, rabbit breeding $8.9 \%$. Moreover, $51 \%$ of respondents said that they have been engaged in private farming for the whole life, $38 \%-5-10$ years, $11 \%-1-5$ years. Residents spend an average of 2 to 6 hours to maintain a household plot, depending on the number of animals and the size of the farmland owned. $72 \%$ of respondents consume the cultivated produce, $23 \%$ - both consume and help their relatives and 5\% grow for sale. The rural population is mainly involved in private farming to provide the family with food. The data show that only $5 \%$ of respondents supply the produce to the market. $69.2 \%$ of respondents sell the produce in farmer markets by themselves, while $30.8 \%$ sell it through reception areas. $86 \%$ of respondents are engaged in processing products, namely, $77 \%$ are engaged in vegetable and berry canning, $33 \%$ in meat and fish canning, $31 \%$ in smoking. Only $4 \%$ sell home-processed products.

Farm management costs are recovered according to $74.3 \%$ of villagers, while $25.7 \%$ not. Over $70 \%$ of respondents spend no more than 50,000 rubles a year on the products intended for further management. $64 \%$ of respondents note that family farming is economically viable, since it is a way to provide them and their relatives with food, employment and partly it is a source of income. $36 \%$ of respondents consider private farming as a money-losing business due to high feed costs and labor-intensive work. In general, private household plots, according to $51.8 \%$ of respondents, yield a substantial profit, both material in the form of obtained and partially sold produce and social in the form of gratitude from relatives and friends.

Household plots have insufficient technical capacities. Only $25 \%$ of respondents have some machinery, mainly mini tractors, potato-diggers, cars, etc. Only $51.4 \%$ of respondents have necessary premises. Auxiliary labor force is used by $20 \%$ of private farmers, though, constantly but only during particularly intense periods of work. It is quite difficult to manage farming business independently. Therefore, according to $42 \%$ of respondents they need to rely on their relatives for assistance, $41 \%$ - on state, $9 \%$ - on state through the sales assistance system and $8 \%$ - on government through the credit system. The villagers are poorly aware of the state support for private farms. Only $42.9 \%$ of respondents have at least the slightest idea. Only $11.4 \%$ of them actually benefited from it. The villagers find it necessary to invest in cooperatives (28.2\% - credit, $28.1 \%$ - purchasing, $26.4 \%$ - sales, $17.3 \%$ service) to contribute to private farming development. The villagers avoid taking loans due to the high interest rate and some uncertainty related to the sales of products and profitmaking. Only $34.3 \%$ of respondents used the services of credit companies. 
Thus, small agribusinesses are an essential part of agricultural production in the Tyumen region. Private farms generate such products, primarily for their own consumption, but some surplus products from the household plot are sold in the market. Consequently, sales and processing issues are important to deal with at the state level. That's what both experts and villagers believe. This issue is addressed in the municipalities, at the regional government level. Agribusinesses of the region are encouraged in accordance with the state program of the Tyumen region The main directions of development of the agro-industrial complex for 2013-2020. The procedure for providing regional and federal budgetary funds is determined by the Government of the Tyumen region [4]. The programs that stimulate residents of the region to develop their household plots all subsidize various costs, support cooperatives providing services to the population. Since 2012, state support measures have been implemented in the region aimed at the creation and development of start-up farms. During the implementation period, 54 newly-established farms were involved in this programme and received grant support. The amount of state support in this area amounted to 60.3 million rubles. The last pre-qualification of novice farmers was held by the commission on October 20, 2016. By the end of the year following the selection procedure another 6 farm owners received grant support for the creation and development of their farms. The novice farmers purchased both from their own and budget funds 81 units of agricultural machinery and equipment, 454 heads of beef and milk cattle, 138 heads of sheep. For 2015 the total revenue of 44 new peasant farms mounted to 41,566 rubles. Farmers' own investments in the development of production amounted to about 8.6 million rubles. 98 employees work in these farms, more than 11.3 thousand hectares of agricultural land are practically used. Through different breeding programs, the Tyumen farms purchased more than 3,600 sows, thus facilitating the improvement of breed character on 20,000 private farms. The program of artificial insemination of cows is being implemented through regional budget. Standards have been developed to achieve high-quality milk procurement both for private farms, primary and centralized reception areas of procurement and for cooperatives. In the Tyumen region, the network of milk reception bases is expanding. Strong family farms are being set up. They receive up to 1 million rubles per year only due to the delivery of milk. [2]. As part of establishing a sustainable resource base for private household plots, the regional program ' $5+$ ' was initiated. It is intended for those who have the strength and desire to increase the number of animals on their farms. The idea of the program is that private farmers receive breeding cattle from a cooperative not for money but for future milk yields. Moreover, villagers should be trained in herd management. The name of the program is related to the modalities of engagement. Private farm owners need to have five cows and over and each pasture-fed cow must produce at least five tons of milk output per year. "Only under such conditions program participants will be able to justify the costs of their support and improve their well-being," said the expert, the developer of the program. To participate in the program, private households must prove their viability and the possibility of personal development. Besides five cows, it is necessary to market milk for processing for a long time and have acceptable veterinary indicators, inter alia, by taking measures to prevent the leukemia. The program includes not only supply of animals to private farms but also consulting support, provision of feed and involvement of cooperatives in this activity. Since 2018, owners of private farms have been trained in the School of Livestock Breeder where teachers from Northern Trans-Ural State Agricultural University deliver knowledge. The School participants obtain certificates. The first successful results of the program were achieved in the Vagay, Iset, Uporovsky districts.

Since 2016, the region has been implementing grant support to agricultural cooperatives to provide the development of their material and technical base. 5 consumer credit cooperatives of the Tyumen region were selected for financial support in 2016, 3 of them purchased 4 specialized cars, facilities for milk cooling and initial processing. Cooperatives received 4,870 rubles from the regional budget. Existing government measures constitute subsidized purchase of agricultural machinery and equipment, subsidies for seed production and livestock breeding, subsidies for technological and engineering equipment for mini-farms. They sufficiently stimulate innovations in small agribusinesses by contributing to the increase in the genetic potential of plants and animals and the development of seed production and livestock breeding.

Measures taken are aimed at increasing the production and sales of produce generated by private household plots and the growth of incomes of the rural population. However, according to experts without the cooperation of private owners, neither advanced agricultural production, nor its sales are possible. The regional government and the heads of municipalities have taken the initiative of settling procurement and credit cooperatives. Anyone who wants to work can take a loan on sufficiently preferential terms to buy animals, feed and sell the produce. As of January, 10, 2018, in the Tyumen region, there are 89 agricultural consumer cooperatives (excluding credit cooperatives) with a total number of members equal to 6980 , including owners of private farms amounting to $6793(98.2 \%)$. The revenue of agricultural consumer cooperatives increases annually. The proceeds of cooperatives are made up of the cost of agricultural products $89 \%$ and income from services $-11 \%$. In 2012, the revenue of cooperatives amounted to 833.8 million rubles. For 2017 this figure was 1477.7 million rubles, having almost doubled. Currently, cooperative services cover about $72 \%$ of rural areas. Purchases of meat, milk, potatoes and wild plants are expanding. 56.500 tons of milk, 2168.2 tons of meat, 1.600 tons of potatoes and vegetables, 0.6 tons of wild plants were purchased in 2017. Services were rendered in the amount of over 120 million rubles. The development of agricultural consumer cooperation is important for maintaining a stable socio-economic situation in rural regions. The existing infrastructure for small agribusinesses contributes to alternative employment for citizens on private farms, stimulates the growth of commodity production in private household plots. For some rural residents, private farms often serve as the main and only source of income. Therefore, the 
established system of consumer cooperation helps to solve economic, organizational and production problems. In this regard, the experience of the Vagaisky and Zavodoukovsky districts is successful. According to the head of the cooperative in the Vagay district the agricultural production cooperative operating in the district actively interacts with private farms through the procurement of milk, potatoes, wild plants, meat, fish, provision of hay, firewood, wood and plowing of gardens. It participates in the construction of minifarms. All district and private sector cooperatives use loans in a credit cooperative. The Deputy Head of the Usadba agricultural cooperative added that with competent organization of cooperative movement, the owners of small farms become independent, raise livestock, etc. The income from small farms is sometimes higher than the salary of oil and gas workers.

Quite active population, according to experts interviewed, lives in the Armizonsky, Zavodoukovsky, Vagaysky, Uporovsky, Vikulovsky districts and others. At the same time, in some territories, the interest to develop animal husbandry is declining, the population is aging and young people are leaving for cities. The decline in production activity is noticeable in the Sorokinsky, Omutinsky, Tobolsk, Nizhnetavdinsky districts.

Along with the positive trends in the development of private farms, there are concerns raised by both experts and respondents that are as follows:

- limited state support necessary for the functioning of private farms

- disinterest in the development of private farms, due to the sale of products and their processing;

- low employment of rural residents on private farms;

- gaps in access to credit resources at optimal rates;

- poorly developed infrastructure in the countryside;

- the ability to conduct extended reproduction.

The problematic issue facing villagers is to acquire the status of a private farm. In 2015, one of the residents of the Tyumen region lost 200 heads of cattle in a fire. He applied for help to the department of the agro-industrial complex but could not get it because he did not have the status of a private household plot. In 2016-2016, following the agitation carried out by the municipalities, about $30-40 \%$ of villagers who have livestock, poultry, etc. on their farm acquired such a status. They were entitled to have legal protection and appropriate support. Therefore, it is necessary to continue educational work towards registering private farms, involving heads of settlements, leaders of cooperatives in order to create an effective set of motivation for citizens to start their own business in the village.

The appearance of dry milk on the market, a decrease in the total volume of dairy consumption, the entry into force of new technical conditions for assessing the quality of raw materials had a significant impact on the fall in the price of raw milk, which created additional problems for those working on private farms. In addition, according to experts, almost a third of the animals in private households are infected with leukemia. These problems need to be addressed by all interested parties including private farms, cooperatives and state authorities.

\section{CONCLUSION}

Thus, the views of A.V. Chayanov on the development of family peasant farms were justified both at the world, allRussian and regional levels. Private household plots were reenergized in the early $21^{\text {st }}$ century along with cooperation. Of course, modern private farming is a far cry from peasant farmsteads of the $20 \mathrm{~s}$ of the $20^{\text {th }}$ century. However they have a common feature, particularly, family self-organized management of agriculture based on personal impact of each member. In the Tyumen region there is a steady positive dynamics of this segment of the agrarian economy. The study made it possible to assert that it is such farms that allow for survival in difficult conditions of economic crisis and unemployment. What is more, they provide an opportunity for self-employment, for obtaining social satisfaction and profit during economic growth. Respectable state support carried out in the region is of great importance in keeping the viability of private farms. The results of the author's research allowed to reveal a number of interrelated problems of modern private farms, which can be solved through the following:

1. Informing villagers about state support;

2. Providing training either on site or remotely in entrepreneurship, organization of private household plots;

3. Establishing advice bureaus for areas of activity (animal husbandry, crop production, plant protection, etc.);

4. Expanding the network of cooperatives;

5. Mitigating credit conditions;

6. Improving health conditions by creating quarantine herds.

\section{References}

[1] Z.T. Vakhitova, The development of farms and private household plots of citizens in the modernization of agricultural production, Thesis for Candidate Degree. Yekaterinburg, 2017, 178 p

[2] In the Tyumen region more private farms have emerged, DairyNews.ru URL:.http://www.dairynews.ru/presentation/v tumenskoj_oblasti stalo bolshe_lichnyh_podsobnyh7307.html.

[3] O.N. Goncharenko, L.B. Medvedeva, Formation of conditions for the functioning of small businesses, News of higher educational institutions. Sociology. Economy. Policy, 2017, No. 4, pp. 26-30.

[4] Information on the implementation of the resolution of the Tyumen Regional Duma of 21.11.2013 No. 1548 "On the development of smal businesses in the agro-industrial complex of the Tyumen Region". URL: http://www.duma72.ru/doc/com_agrar/2016.

[5] P.A. Kropotkin, Mutual assistance as a factor of evolution: Editorial Board of the magazine "Self-education", Moscow, 2007 URL:http://www.dragondreaming.org/ru/wpcontent/uploads/sites/11/2016/04/Kropotkin_P_A__zaimopomosch_ka k_faktor_evolyutsi.pdf. 
[6] A.E. Naumova, Organization of Crediting of Private Farms (on the example of the Belgorod Region, Abstract of Thesis for Candidate Degree, SPb., 2008, 22 p.

[7] A.A. Nikonov, Prospects for agrarian reform: the strategy of the transition period, AIC: Economics, Management, 1993, № 7, pp.26-30.

[8] On the State Program for the Development of Agriculture and Regulation of Agricultural Products, Raw Materials and Food Markets for 2013-2020 (as amended on July 29, 2017. Resolution of the Government of the Russian Federation No. 717 of July 14, 2012. URL: http://docs.cntd.ru/document/902361843.

[9] About private farming. The law of the Tyumen region of March 27, 1998. URL: https://law.admtyumen.ru/law/index.htm.

[10] V.N. Plotnikov, Private Farming: Big Problems of Small Businesses, Bulletin of Volgograd State University, Series 3, Economics. Ecology. 2010, No. 2 (17), pp.89-95.

[11] E.A. Puzyreva, The development of private farms. Thesis for Candidate Degree, M.: 2009, 160 p.
[12] Yu.I. Tarasov, N.Yu. Mugu, Ways of development of private household plots, New technologies, 2009, No. 3, pp.1-4.

[13] A.V. Chayanov, Peasant economy. Selected Works, M., 1989. URL: http://chayanov2.blogspot.com/.

[14] A.V. Chayanov, The main ideas and forms of organization of agricultural cooperation, M., 1919. URL:68 c. http://chayanov1.blogspot.com/.

[15] N.M. Shulga, The development of private farming in the modern economic conditions, Innovative Economy: Materials of the II Intern. scientific conf. (Kazan, October 2015), Kazan: Beech, 2015, pp. 9-11.

[16] Nursafa Gafurovna Khairullina, Oksana Vyacheslavovna Ustinova,Galina Vladimirovna Kuchterina, Lyudmila Georgievna Agapitova and Lyubov Borisovna Medvedeva Set of value in the structure of labor behavior of personnel MII-MII(-SP) - Man In India (ISSN00251569-India-Scopus), №96 (10), 2016 г. - c.3949-3960G. Eason, B. Noble, and I.N. Sneddon, "On certain integrals of LipschitzHankel type involving products of Bessel functions," Phil. Trans. Roy. Soc. London, vol. A247, pp. 529-551, April 1955. 